\title{
APLIKASI POINT OF SALES JASA FOTO DAN VIDEO KULA VISUEL BERBASIS ANDROID
}

\author{
Adji Wicaksono ${ }^{1}$, Forkas Tiroy Santos Butarbutar ${ }^{2}$, Intan Vandini ${ }^{3}$ \\ ${ }^{1,2,3}$ Teknik Informatika, Fakultas Teknik dan Ilmu Komputer, Universitas Indraprasta PGRI \\ PGRI Jakarta, Jalan Raya Tengah No 80, Kelurahan Gedong, Pasar Rebo, Jakarta Timur \\ 1adjiwicaksono277@gmail.com, ${ }^{2}$ ftsb43dharma@gmail.com, $\underline{3 \text { intanvandini25@gmai.com }}$
}

\begin{abstract}
ABSTRAK
Di dalam Aplikasi point of sales jasa foto dan video ini terdapat beberapa halaman yang membantu untuk mempermudah proses presentasi juga pemesanan kepada pelanggan yang akan memesan terdapat halaman profil yang berisi sekilas tentang Kula Visuel, halaman layanan yang berisikan tentang portofolio foto dan video yang telah dikerjakan oleh Kula Visuel serta terdapat harga paket disetiap masih-masing layanan, halaman data untuk mencetak data pemesanan, data pelanggan, data layanan dan data tim, serta halaman reservasi yang berguna untuk melakukan pemesanan paket foto dan video tersebut. Metode penelitian yang digunakan untuk menganalisis aplikasi yang dibuat adalah observasi langsung dan wawancara. Untuk tahap pembuatan aplikasi dimulai dari analisa kebutuhan, perancangan sistem, desain aplikasi dan pengujian. Metode pengembangan yang digunakan yaitu metode waterfall. Aplikasi dibuat dengan menggunakan software editor android studio dan database firebase Akhirnya penulis menarik kesimpulan bahwa hasil dari penelitian aplikasi point of sales jasa foto dan video kula visual ini dapat berdampak meningkatkan efektifitas dalam pelayanan pelanggan.
\end{abstract}

Kata Kunci: Aplikasi, point of sales jasa foto dan video

\begin{abstract}
In this photo and video service point of sales application there are several pages that help to simplify the presentation process as well as ordering to customers who will order there is a profile page that contains a glimpse of Kula Visuel, a service page that contains a portfolio of photos and videos that have been done by Kula Visuel and there are package prices for each service, a data page for printing order data, customer data, service data and team data, as well as a reservation page that is useful for ordering the photo and video packages. The research method used to analyze the application made is direct observation and interviews. For the application creation stage, starting from requirements analysis, system design, application design and testing. The development method used is the waterfall method. The application is made using the android studio editor software and the firebase database. Finally, the authors conclude that the results of the research on the point of sales application for photo and video services can have an impact on increasing effectiveness in customer service.
\end{abstract}

Key Word: Applications, point of sales foto and video services

\section{PENDAHULUAN}

Pada saat ini segala hal sangat cepat berkembang salah satunya adalah teknologi informasi yang semakin hari semakin pesat kemajuannya. Dengan adanya kemajuan teknologi yang sangat canggih maka segala kegiatan dan kebutuhan sehari-hari akan mudah untuk terpenuhi dan terselesaikan. Kemajuan teknologi juga pastinya harus dimanfaatkan dengan sebaik dan semaksimal mungkin terlebih bagi pelaku usaha dalam menjalankan usahanya. Usaha yang ditawarkan dapat berupa barang maupun jasa, Jasa adalah setiap tindakan atau aktivitas yang dapat diberikan oleh satu pihak kepada pihak lain, yang sifatnya tidak berwujud dan tidak mengarah pada kepemilikan apa pun.(Nurcholifah, 2014), salah satunya adalah dokumentasi, jasa dokumentasi sangatlah dibutuhkan semua orang untuk mengabadikan seluruh kegiatan maupun momenmomen terpenting dalam kehidupannya.

Dengan berkembangnya teknologi yang canggih saat ini, banyak dari pengusaha menengah sampai ke atas yang sudah memanfaatkan penggunaan teknologi untuk mempermudah pekerjaannya dan lebih efektif serta lebih efisien dalam menghemat waktu. Kemajuan teknologi ini sangat menguntungkan bagi seluruh pemilik usaha yang paham akan teknologi. Jasa dokumentasi memberikan pelayanan dalam pembuatan foto dan video keberlangsungan acara maupun pengabadian momen-momen yang ingin diabadikan seperti foto dan video pranikah, acara 
pernikahan, pesta ulang tahun, serta acaraacara tertentu. Aplikasi merupakan program yang terbuat oleh pemakai yang diperuntukan buat melaksanakan sesuatu tugas khusus (Fikry, 2019:8). Selain itu, Aplikasi merupakan program siap pakai ataupun program yang dirancang guna men- jalankan peranan untuk pengguna ataupun aplikasi lain (Pratomo, 2020:3). kemajuan teknologi dapat membantu segala aspek kehidupan dalam membuat, mengubah, maka penulis bermaksud untuk melakukan penelitian dan merancang aplikasi pemesanan yang diharapkan dapat bermanfaat untuk Kula Visuel. Penelitian tersebut sekaligus dijadikan judul skripsi atau tugas akhir dengan judul "Rancang Bangun Aplikasi Point Of Sales Jasa Foto Dan Video Kula Visuel Berbasis Android".

\section{METODE PENELITIAN}

Metode penelitian adalah metodologi yang dipilih oleh para ilmuwan untuk menggabungkan dan memimpin percakapan total bagian-bagian eksplorasi dengan cara yang sah dan tepat, seperti membedah substansi yang terkandung dalam komunitas pemeriksaan. Teknik pemeriksaan yang digunakan pencipta untuk mengarahkan penelitian adalah strategi subjektif. Dari hasil penyelidikan ini, para pencipta memimpin pemeriksaan yang pasti atas informasi yang didapat dari lapangan. Data yang sudah dianalisa dan diolah kemudian dibuat sebuah kesimpulan, selanjutnya penulis membuat laporan untuk melampirkan kegiatan yang dilakukan selama proses penelitian di Program Studi Teknik Informatika, Fakultas Teknik dan Ilmu Komputer. Adapun metode pengumpulan data yang digunakan penulis dalam menyusun penelitian antara lain:

\section{Wawancara}

Metode wawancara merupakan dialog untuk tujuan tertentu. Wawancara merupakan teknik pengumpulan data yang dilakukan melalui tanya jawab langsung antara peneliti dan narasumber.

2. Metode Observasi

Pengertian metode observasi yang paling sederhana adalah mengamati dan mendengarkan kejadan atau tindakan yang dilakukan oleh pengamat, kemudian menggunakan catatan atau alat bantu lainnya untuk mencatat hasil observasi tersebut.

3. Sumber Data Melalui Website Yang Ada Di Internet

Penulis mengunjungi beberapa website untuk mengumpulkan artikel dan kutipan yang berkaitan dengan penelitian ini.

Dalam buku yang bertajuk Sikap Organ- isasi oleh (Duha, 2018: 2) Organisasi merupakan kesatuan yang tercipta oleh sebagian orang yang mempunyai sedikit ataupun seluruh kesamaan tentang latar balik, bukti diri, harapan serta bermacam perihal yang lain buat menggapai tujuan Bersama secara bersamasama, berikut struktur organisasi kula visual:

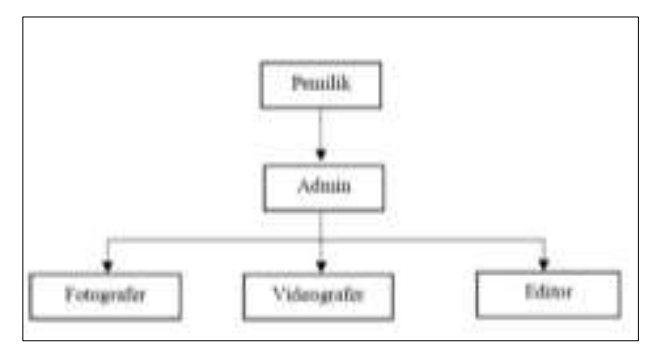

Gambar 1. Struktur Organisasi

Analisis sistem diharapkan dapat membedah perilaku sistem saat ini dan memecah jalan menuju masuk dan meninggalkan informasi atau arsip pada sistem saat ini sehingga sistem yang akan dibuat dapat membidik kebutuhan pelanggan dan tepat sasaran, pada Kula Visuel sistem yang digunakan masih begitu sederhana sehingga dalam proses pemesanan pun masih cukup konvensional, sistem yang masih sederhana cukup sering menyebabkan kesalahan dalam melakukan pemesanan maupun pencatatan data, berikut activity diagram sistem Kula Visuel, berikut gambar diagram Activity diagram pemesanan yang sedang berjalan.

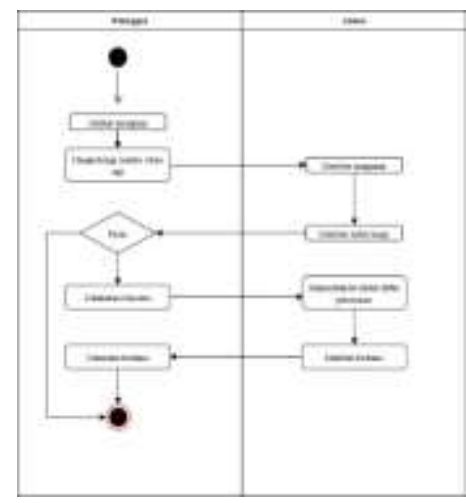

Gambar 2. Activity Diagram Proses Pemesanan 
Berdasarkan hasil Analisa, wawancara dan observasi penulis dengan pemilik Kula Visuel sistem pemesanan paket dokumentasi foto dan video yang digunakan masih menggunakan sistem secara manual dengan memanfaatkan perangkat atau software yang sudah ada seperti menggunakan Microsoft Power Point untuk menunjukan daftar harga paket serta portofolio yang ada dan menggunakan Microsoft Excel untuk mendata pesanan yang telah dipesan oleh pelanggan. Dengan ini penulis ingin menganalisa dan menguraikan permasalahan dan hambatan yang terdapat pada sistem berjalan ini.

Dengan melihat masalah yang ada pada sistem pemesanan manual Kula Visuel maka, penulis mengusulkan untuk membuat rancang bangun sistem aplikasi berbasis android untuk mempermudah proses pemesanan paket jasa dokumentasi foto dan video pada Kula Visuel dengan membuat sistem yang sudah terkomputerisasi untuk meminimalisir kesalahankesalahan yang sekiranya akan terjadi karena kelalaian manusia karena sistem yang dibuat telah terintegrasi dengan baik.

\section{HASIL DAN PEMBAHASAN}

Use Case Diagram adalah diagram yang menunjukkan sekumpulan kasus penggunaan dan actor (Radityanto dan Sularsih, 2018:22). Diagram ini memiliki 2 fungsi yaitu mendefinisikan fitur apa yang harus disediakan oleh sistem dan menyatakan sifat sistem dari sudut pandang user.

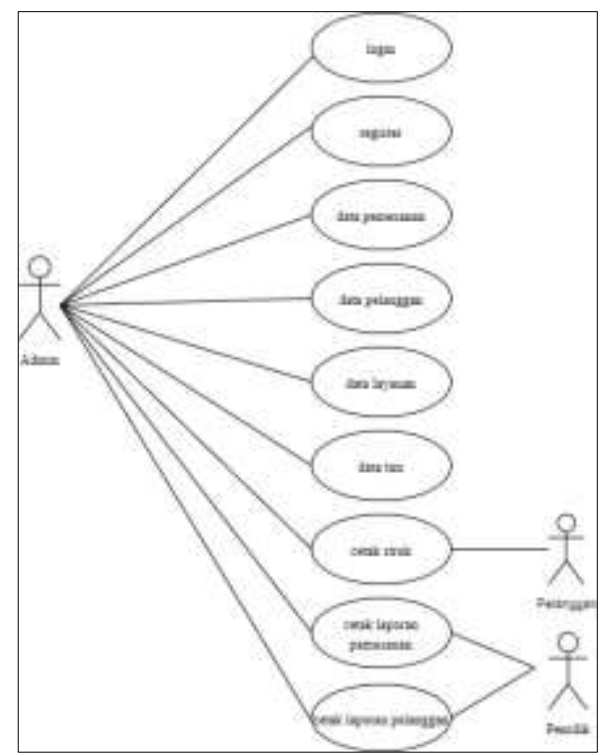

Gambar 3. Use Case Diagram
Pada use case diagram diatas terdapat tiga aktor, admin, pemilik dan pelanggan, admin memiliki akses untuk login, register, mencetak data pemesanan, pelanggan, layanan, tim serta dapat mencetak struk, laporan pemesanan, laporan pelanggan, pemilik dapat menerima hasil cetak laporan pemesanan dan laporan pelanggan dan pelanggan mendapatkan struk pemesanan yang telah dipesan.

Activity diagram merupakan diagram yang menunjukkan aliran dari suatu aktivitas ke aktivitas lain dalam sistem dan mempunyai fungsi untuk menganalisis aliran (Ayu \& Permatasari, 2018).

Selain itu, diagram aktivitas dibuat berdasarkan aliran dasar dan aliran alternatif dalam skenario diagram use case diagram. Activity diagram menggambarkan interaksi antara peserta dan sistem dalam diagram use case (Dellarosawati, 2020).

Pada diagram activity ini dijelaskan bahwa pelanggan melakukan pemesanan paket foto dan video pada halaman reservasi pada halaman ini pelanggan diminta mengisi nama lengkap, email, alamat, nomor telepon, layanan, tanggal pemesanan dan tanggal pelaksanaan, setelah mengisi data dan mengklik tombol selanjutnya sistem akan memunculkan halaman transaksi dimana pengguna dapat memilih ingin melakukan transaksi dengan metode pembayaran tunai atau dengan transfer jika pelanggan memilih pembayaran transfer, sistem akan memunculkan bank tujuan serta nomor rekening tujuan pembayaran, jika pelanggan memilih tunai makan akan langsung masuk ke halaman struk

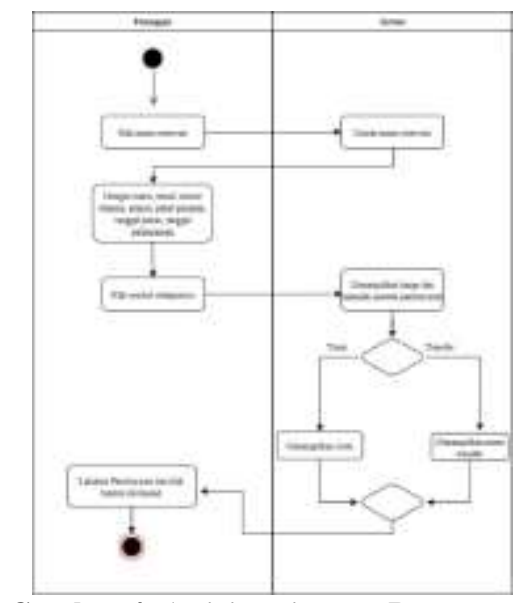

Gambar 4. Activity Diagram Pemesanan 
Dibawah ini merupakan entity relationship diagram atau ERD adalah sebuah diagram structural yang digunakan untuk merancang sebuah database. Sebuah ERD mendeskripsikan data yang akan disimpan dalam sebuah sistem maupun batasannya (Latukolan, Aran \& Ananta, 2019). Pada gambar ERD terdapat dua buah id yaitu user dan pemesanan dan masing-masing id memiliki field berdasarkan fungsinya.

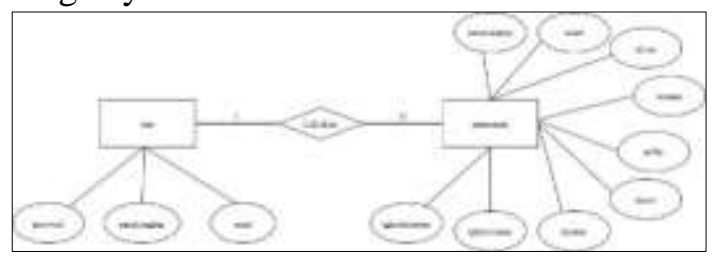

Gambar 5. ERD (Entity Relationship Diagram)

Class diagram menggambarkan struktur sistem dengam mendefinisikan kelas- kelas yang akan digunakan untuk membangun sistem (Ananda, 2018).

Class diagram adalah diagram statis. Ini mewakili pandangan statis dari suatu aplikasi. Class diagram tidak hanya digunakan untuk memvisualisasilan, memggambarkan, dan mendokumentasikan berbagai aspek sistem tetapi juga untuk membangun kode eksekusi (executable code) dari aplikasi perangkat lunak (Candra \& Putra, 2021).

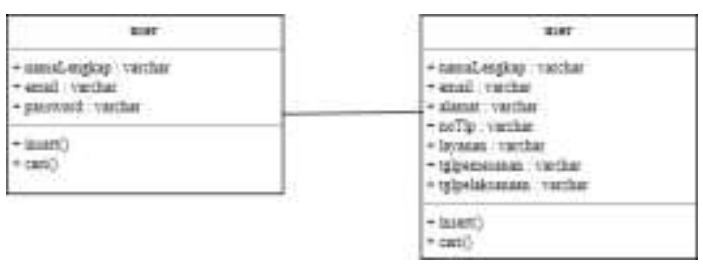

Gambar 6. Class Diagram

Berdasarkan hasil dan pembahasan diatas, penulis membuat aplikasi point of sales jasa foto dan video untuk mempermudah proses persentasi admin serta pemesanan dan transaksi pelanggan. Berikut tampilan layar dari aplikasi yang dibuat:

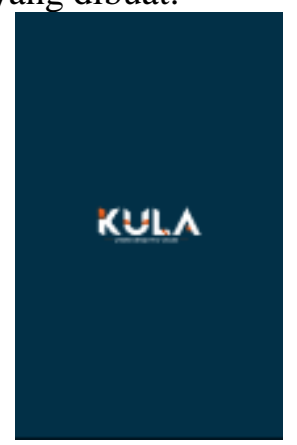

Gambar 7. Tampilan layar splash screen
Tampilan splash screen adalah tampilan awwal ketika kita membuka aplikasi, splash screen akan muncul selamat lima detik dan selanjutnya akan berpindah dengan sendirinya ke tampilan berikutnya.

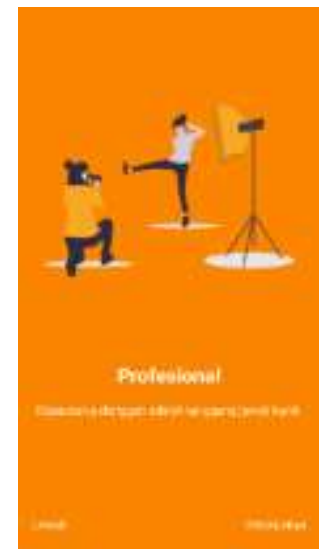

\section{Gambar 8. Tampilan layer on boarding}

Tampilan on boarding berguna memperkenalkan gambaran kecil mengenai kula visuel.

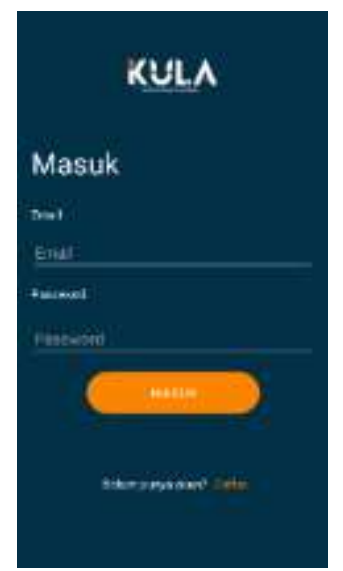

Gambar 9. Tampilan layar halaman masuk

Tampilan layar halaman masuk bergunna untuk melakukan validai pelanggan yang akan masuk ke dalam aplikasi.

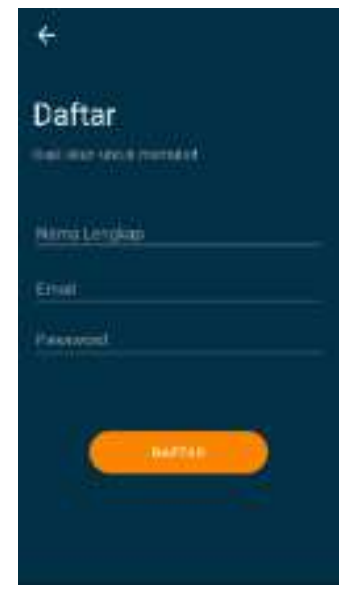

Gambar 10. Tampilan layar halaman daftar 
Tampilan layar halaman daftar berguna untuk melakukan pendaftaran agar dapat melakukan validasi pada halaman masuk.

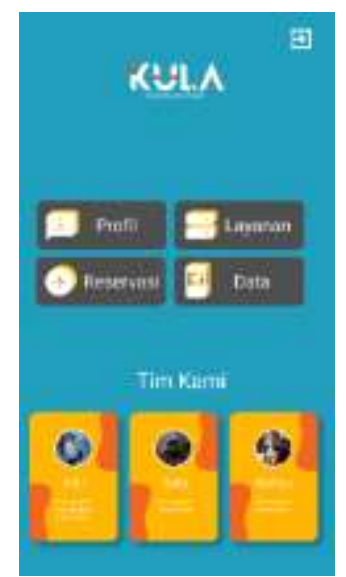

Gambar 11. Tampilan layar halaman utama

Tampilan layar halaman utama terdapat empat menu yaitu menu profil, laporan, reservasi dan data, serta terdapat profil singkat tim kula visuel.

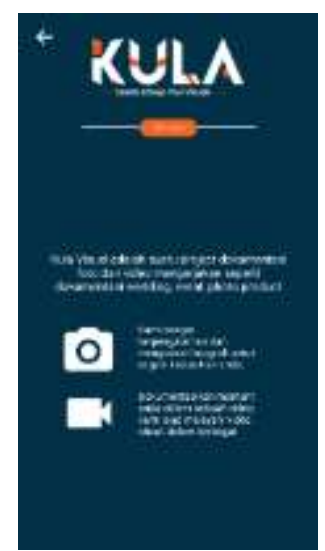

Gambar 12. Tampilan layar menu profil

Tampilan layar menu profil berisikan profil singkat mengenai kula visual

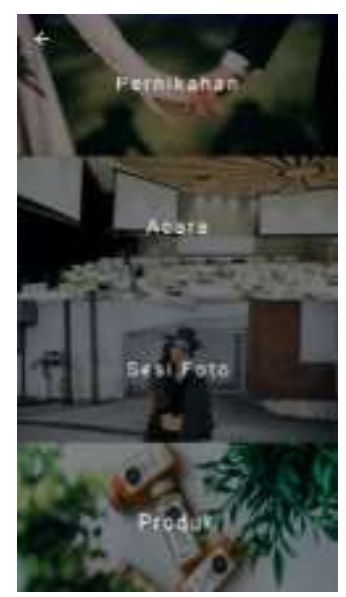

Gambar 13. Tampilan layar menu layanan
Tampilan menu layanan terdapat layananlayanan yang ditawarkan oleh kula visual seperti pernikahan, acara, sesi foto dan produk.

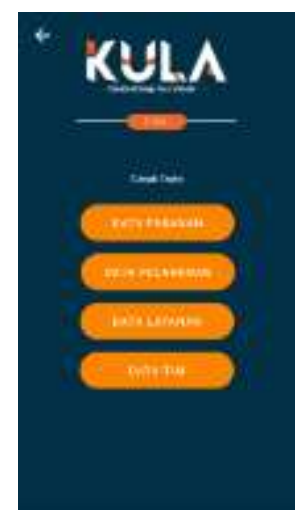

Gambar 14. Tampilan layar menu data

Tampilan layar menu data terdapat empat data yang dapat dicetak yaitu data pesanan, pelanggan, layanan dan data tim.

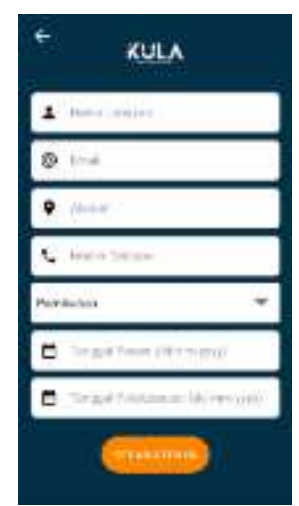

Gambar 15. Tampilan layar menu reservasi

Tampilan layar menu reservasi terdapat form reservasi yang dilakukan untuk melakukan pemesanan layanan oleh pelanggan.

Diagram sequence dibuat berdasarkan diagram aktivitas dan diagram kelas dibuat, kemudian diagram sequence menggambarkan aliran pesan yang terjadi antar kelas menggunakan operasi yang termasuk kelas tersebut (Sulistyorini, 2009).

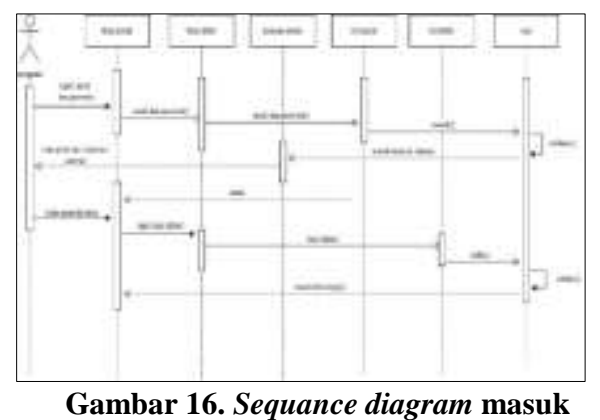


Pada sequence diagram masuk terapat alur sistem dimana pengguna harus melakukan pendaftaran pada halaman daftar dan mengisi data yang diminta lalu masuk Kembali ke halaman masuk untuk melakukan validasi data proses masuk.

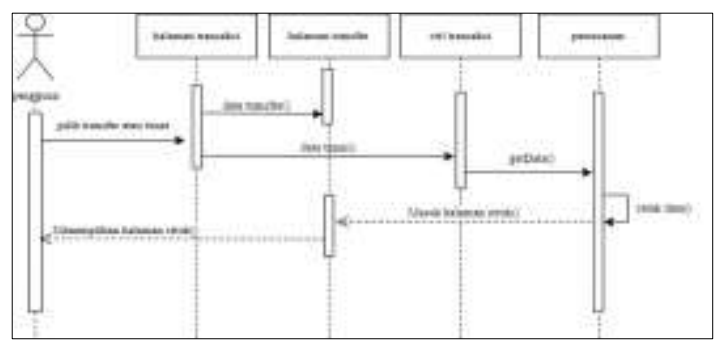

Gambar 17. Sequance diagram struk pemesanan

Pada sequence diagram struk pemesanan dijelaskan bagaimana tahapan mendapatkan struk pemesanan.

\section{SIMPULAN}

Simpulan dari penelitian skripsi yang berjudul "Rancang Bangun Aplikasi Point Of Sales Paket Foto Dan Video Kula Visuel Berbasis Android" adalah sebagai berikut :

Telah berhasil dibangun Aplikasi Point Of Sales Jasa Foto Dan Video Kula Visuel yang bertujuan sebagai alat pemesanan yang lebih praktis dan mudah digunakan untuk melakukan pemesanan paket foto dan video.

Di dalam Aplikasi point of sales jasa foto dan video ini terdapat beberapa halaman yang membantu untuk mempermudah proses presentasi juga pemesanan kepada calon pelanggan yang akan memesan terdapat halaman profil yang berisi sekilas tentang Kula Visuel, halaman layanan yang berisikan tentang portofolio foto dan video yang telah dikerjakan oleh Kula Visuel serta terdapat harga paket disetiap masih-masing layanan, halaman data untuk mendownload data pemesanan dan data pelanggan, serta halaman reservasi yang berguna untuk melakukan pemesanan paket foto dan video tersebut.

Dengan adanya Aplikasi Point Of Sales Paket Foto Dan Video Kula Visuel ini memudahkan admin untuk melakukan presentasi dengan calon pelanggan, serta memudahkan pelanggan untuk melakukan pemesanan paket foto dan video. Antarmuka yang sederhana dapat mempermudah admin untuk mempelajari sistem ini.

\section{DAFTAR PUSTAKA}

Ananda, A. N. (2018). Mobile Commerce Berbasis Android Pada PT. Mega Mulia Pharma Palembang. Politeknik Negeri Sriwijaya.

Ayu, F., \& Permatasari, N. (2018). Perancangan Sistem Informasi Pengolahan Data PKL (Praktek Kerja Lapangan) Di Devisi Humas Pada PT Pegadaian. Jurnal Intra Tech, 2(2), 1226.

Candra, M., \& Putra, T. (2021). Rancang Bangun Mobile Learning Berbasis Android Untuk Memudahkan Proses Belajar Mengajar Jarak Jauh Di Smkn Sukaresik-Skp. Pti 0006. universitas Muhammadiyah Tasikmalaya.

Dellarosawati, M. (2020). Riset Teknologi Finansial Untuk Umkm Dalam Menunjang Laporan Keuangan. Methosika: Jurnal Akuntansi Dan Keuangan Methodist, 3(1), 33-38.

Duha, T. (2018). Perilaku organisasi. Deepublish.

Fikry, M. (2019). Aplikasi Java Kriptografi Menggunakan Algoritma Vigenere. TECHSI-Jurnal Teknik Informatika, 8(1), 1-9.

Latukolan, M. L. A., Arwan, A., \& Ananta, M. T. (2019). Pengembangan Sistem Pemetaan Otomatis Entity Relationship Diagram Ke Dalam Database. Jurnal Pengembangan Teknologi Informasi Dan Ilmu Komputer E-ISSN, 2548, 964X.

Nurcholifah, I. (2014). Strategi marketing mix dalam perspektif syariah. Jurnal Khatulistiwa LP2M IAIN Pontianak, 4(1), 73-86.

Pratomo, A. (2020). Pembangunan Akses Pintu Masuk Stadion GBLA Dengan Kartu RFID Sebagai Tiket Dan Terintegrasi Dengan Aplikasi Pemilihan Nomor Kursi Penonton Berbasis Android. Universitas Komputer Indonesia.

Radityanto, A., \& Sularsih, P. (n.d.). Pembuatan Web Aplikasi Penjualan Barang Elektronik.

Sulistyorini, P. (2009). Pemodelan visual dengan menggunakan uml dan rational rose. Dinamik, 14(1). 